\title{
Analisis Obyek Daya Tarik Wisata Dan Aksesbilitas Terhadap Minat Berkunjung Wisatawan Di Pantai Baru Yogyakarta
}

\author{
Anwani \\ STIE "Pariwisata API" Yogyakarta \\ Jl. Tambak Bayan No.15, Caturtunggal, Kec. Depok, Kabupaten Sleman, Daerah Istimewa \\ Yogyakarta 55281 \\ E-Mail: aaanwani@gmail.com
}

\begin{abstract}
Abstrak
Pantai Baru diresmikan sebagai obyek wisata pada Mei 2010. Pantai Baru dijuluki sebagai pantai kincir angin, karena di kawasan Pantai Baru berdekatan dengan lokasi pembangkit listrik tenaga kincir angin. Mengingat Pantai Baru masih tergolong muda di Yogyakarta maka wisatawan yang berkunjung masih tergolong sedikit sehingga diperlukan dukungan pengembangan dari berbagai pihak dalam upaya memajukan pariwisata di Yogyakarta. Tujuan dalam penelitian adalah untuk mengetahui terdapat seberapa besar obyek daya tarik wisata dan aksesbilitas berpengaruh pada minat wisatawan yang berkunjung ke Pantai Baru Yogyakarta. Penelitian ini merupakan jenis penelitian deskripsif kuantitatif. Populasi dalam penelitian ini sebanyak 100 responden. Sedangkan Sampel dalam penelitian ini adalah wisatawan nusantara dengan umur 17 tahun keatas yang sedang dan pernah berkunjung ke obyek wisata Pantai Baru Yogyakarta. Teknik pengambilan sampel adalah non probability sampling. Metode penelitian melalui observasi yang dilakukan dengan penyebaran kuisioner untuk mengamati variabel obyek daya tarik wisata, aksesbilitas, dan minat wisatawan yang sedang berkunjung ke Pantai Baru. Variabel penelitian terdiri dari variabel bebas (meliputi obyek daya tarik wisata dan aksesbilitas) dan variabel terikat adalah minat berkunjung wisatawan). Hasil penelitian pada uji $t$ dan uji $F$ menunjukkan obyek daya tarik wisata dan aksebilitas berpengaruh positif terhadap minat berkunjung wisatawan.
\end{abstract}

Kata kunci : Obyek Daya Tarik Wisata, Aksessbilitas, Minat Berkunjung

\section{Analysis of the Objects of Tourist Attractions and Accessibility Towards Tourist Visiting Interest On Pantai Baru Yogyakarta}

\begin{abstract}
Pantai Baru was inaugurated as a tourist attraction in May 2010. Baru Beach is nicknamed the windmill beach, because the Pantai Baru area is close to the location of a windmill power plant. Considering that Pantai Baru is still relatively young in Yogyakarta, tourists who visit are still relatively few so that development support is needed from various parties in an effort to promote tourism in Yogyakarta. The purpose of this research is to find out how much tourist attraction and accessibility have an effect on the interest of tourists visiting Pantai Baru Yogyakarta. This research is a descriptive quantitative research. The population in this study were 100 respondents. While the sample in this study were domestic tourists aged 17 years and over who were and had been to the tourist attraction of Pantai Baru Yogyakarta. The sampling technique is non probability sampling. The research method is through observations carried out by distributing questionnaires to observe the variables of tourist attraction objects, accessibility, and interests of tourists who are visiting Baru Beach. The research variable consisted of the independent variable (covering the object of tourist attraction and accessibility) and the dependent variable was the interest in visiting tourists). The results of the research on the t test and $F$ test show that the object of tourist attraction and accessibility has a positive effect on the interest in visiting tourists.
\end{abstract}

Keyword: Object of Tourist Attraction, Accessibility, Visiting Interest

\section{PENDAHULUAN}

Daerah Istimewa Yogyakarta adalah provinsi yang kaya akan potensi wisata seperti obyek wisata Pantai Baru yang diresmikan pada Mei 2010. Pada awal pembukaan Pantai Baru banyak dikunjungi pengunjung terutama para nelayan. Pantai Baru dijuluki sebagai pantai kincir angin, karena di kawasan Pantai Baru berdekatan dengan lokasi pembangkit listrik tenaga kincir angin. Di areal Pantai Baru banyak terdapat warung kuliner seperti seafood. Mengingat Pantai Baru masih tergolong muda di Yogyakarta maka wisatawan

http://ejournal.bsi.ac.id/ejurnal/index.php/khasanah 
yang berkunjung masih tergolong sedikit sehingga untuk mendukung pengembangan pariwisata di Yogyakarta peneliti tertarik untuk meneliti tentang minat berkunjung wisatawan di Pantai Baru Yogyakarta.

Meskipun tergolong baru, pesona keindahan Pantai Baru tidak kalah menarik dengan pantai-pantai lainnya yang ada di Yogyakarta. Pantai Baru tergolong besar, memanjang sepanjang $4 \mathrm{~km}$. Alamnya teduh, ditumbuhi pohon-pohon cemara di sepanjang bibir pantai. Suasana tersebut sangat cocok bagi wisatawan untuk bersantai. Panjang Pantai Baru sejauh 4000m, dimulai dari Pantai Kuwaru hingga ke muara Sungai Progo.

Keberadaan Pantai Baru sudah ada sejak lama, dan lokasinya berdekatan dengan model percontohan sistem inovasi daerah berupa Pembangkit Listrik Tenaga Surya (solarcell) dan Angin (kincir angin).

Namun demikian karena Pantai Baru tergolong pantai yang masih muda dalam perkembangannya, maka Pantai Baru belum terlalu familiar dikenal wisatawan sehingga minat berkunjung wisatawan masih tergolong sedikit, sehingga keberadaan Pantai Baru perlu mendapat perhatian dari banyak pihak, termasuk dari akademisi untuk dilakukan pengkajian melalui kegiatan penelitian dengan tujuan untuk mengetahui berbagai aspek yang berpengaruh terhadap minat berkunjung wisatawan, diantaranya yaitu faktor obyek daya tarik wisata dan aksesbilitas.

\section{KAJIAN PUSTAKA}

\section{Pengertian Pariwisata}

Menurut UU No.10 Tahun 2009 istilah kepariwisataan berasal dari akar kata wisata. Wisata adalah Kegiatan perjalanan yang dilakukan oleh seseorang atau sekelompok orang dengan mengunjungi tempat tertentu untuk tujuan rekreasi, pengembangan pribadi, atau mempelajari keunikan daya tarik wisata yang dikunjungi dalam jangka waktu sementara. Seseorang atau sekelompok orang yang melakukan kegiatan perjalanan, disebut sebagai wisatawan. Menurut UU No.10 Tahun 2009 tentang kepariwisataan, kepariwisataan adalah Keseluruhan kegiatan yang terkait dengan pariwisata dan bersifat multidimensi yang muncul sebagai wujud kebutuhan setiap orang untuk berinteraksi dengan masyarakat setempat dan sesama wisatawan (Wondama et al.,2019).

Menurut Wondama et al., (2019) mengutip dari Soemarwoto (2001), kepariwisataan menurut UU RI No.10 Tahun 2009 adalah berbagai macam kegiatan wisata dan didukung berbagai fasilitas serta layanan yang disediakan oleh masyarakat, pengusaha, Pemerintah, dan Pemerintah Daerah. Secara global maupun dalam skala nasional, pariwisata merupakan sektor ekonomi penting.

Menurut Hakim (2016) mengutip dari Nyoman S. Pendit (1986), Bapak pariwisata dunia Prof. Hunzikar dan Prof. Krapf, menjelaskan konsep pariwisata adalah sejumlah hubungan-hubungan dan gejalagejala yang dihasilkan dari tinggalnya orangorang asing, yang menyebabkan timbulnya usaha-usaha yang bersifat sementara atau permanen sebagai usaha mencari kerja penuh. Mengutip dari E. Guyer Freuler dalam Pendit (1986), Pariwisata adalah gejala saat ini yang didasarkan atas kebutuhan dan penilaian sadar, kesenangan dan kenikmatan alam.

\section{Industri Pariwisata}

Menurut Hakim (2016) mengutip dari A.S. Hornby, (1978) Kegiatan di dalam industri memerlukan kerja keras untuk dapat berhasil, yang menghasilkan produk untuk memberikan kepuasan dan kesejahteraan untuk manusia. Industri memiliki pengertian suatu usaha untuk menghasilkan produk berupa rangkaian barang atau jasa yang memiliki segi ekonomis, sosial dan psikologis. Mengutip dari Kadin Industri pariwisata terdiri dari tiga jenis sarana yaitu:

(1) Sarana Pokok (Main Tourism Supra Structure), yaitu perusahaan-perusahaan yang kelangsungan hidupnya tergantung kepada ada atau tidak adanya wisatawan. Kategori ini adalah Travel Agencis, Tourist Transportation, Accomodation/Hotel, dan lainnya, Catering Trade, Tourist Objects, Souvenir; (2) Sarana Pelengkap (Suplementing Tourism Supra Structure), yaitu perusahaan-perusahaan dengan sarana pelengkap berfungsi untuk membuat para wisatawan merasa senang, betah, kerasan, hingga mereka ingin tinggal lebih lama disuatu tempat atau daerah wisata. Kategori ini adalah Swimmingpool, Tennis Court, Golf Course, Recreation Centre dan lain sebagainya; (3) Sarana Penunjang (Supporting Tourism Supra Structure), yaitu perusahaanperusahaan dengan sarana penunjang berfungsi untuk membuat wisatawan lebih lama tinggal atau berdiam pada suatu tempat atau daerah wisata dengan lebih banyak mengeluarkan uangnya di tempat yang mereka kunjungi. Kategori ini adalah Night Club, Steambath, Casino. 


\section{Jenis Pariwisata}

Menurut Fajri \& Riyanto E.S, (2016) Mengutip dari Prasasia dan Kusudianto, berdasarkan ciri-cirinya pariwisata dapat digolongkan menjadi: (1) Tujuan wisata sumber daya alam, misalnya iklim, pantai dan hutan; (2) Tujuan wisata sumber daya budaya, misalnya tempat bersejarah, museum, teater dan masyarakat local; (3) Fasilitas rekreasi, misalnya fasilitas taman hiburan; (4) Kegiatan (Event), misalnya pesta atau pertunjukan kesenian dan pasar malam; (5) Aktifitas spesifik, misalnya kasino dan wisata Belanja; (6) Aspek daya tarik psikologis, misalnya petualangan, perjalanan romantis dan situasi terpencil.

Menurut Hakim (2016) mengutip dari Pendit jenis pariwisata terdiri dari: (1) Wisata budaya Dimaksudkan wisata yang ingin mengetahui keadaan kesenian, kebudayaan daerah/negara yang dikunjunginya. Tujuannya untuk memperluas pandangan hidup; (2) Wisata kesehatan adalah perjalanan seorang wisatawan untuk menukar tempat dari tempat sehari-hari dimana wisatawan tinggal untuk beristirahat; (3) Wisata olahraga adalah wisata dengan melakukan perjalanan untuk melakukan olahraga; (4) Wisata komersil Kategori ini adalah perjalanan untuk melihat/mengunjungi pameran-pameran yang bersifat komersil, seperti pameran industri; (5) Wisata industri Wisata ini ada hubungannya dengan wisata-wisata komersil. Dilakukan biasanya dengan mengunjungi kompleks perindustrian, pabrik-pabrik dan semacamnya; (6) Wisata politik Jenis ini dilakukan untuk mengambil bagian dengan aktif dalam peristiwa kegiatan politik, seperti HUT RI 17 Agustus di Jakarta; (7) Wisata konvensi Wisata konvensi hampir sama dengan wisata politik. Jenis ini seperti penyediaan ruang bersidang para peserta suatu konferensi, contohnya Jakarta Convention Centre; (8) Wisata sosial adalah wisata dengan perjalanan murah bagi golongan masyarakat dengan taraf ekonomi rendah.; (9) Wisata pertanian Wisata ke proyek pertanian, pembibitan, ladang untuk tujuan studi bagi para wisatawan.; (10) Wisata maritim (marina) atau wisata bahari adalah wisata di air, danau, bengawan, pantai, teluk atau laut. Kegiatannya seperti memancing, menyelam dan sejenisnya; (11) Wisata cagar alam adalah wisata berkunjung di lokasi cagar alam, taman hutan lindung dan semacamnya; (12) Wisata buru dilakukan di hutan yang diperbolehkan untuk berburu bagi para wisatawan; (13) Wisata pilgrim adalah wisata yang berkaitan dengan agama, sejarah, adat istiadat dan kepercayaan dalam masyarakat. Biasanya datang ke tempat suci, makam orang besar dan orang yang diagungkan; (14) Wisata bulan madu adalah wisata yang dilakukan oleh pengantin baru untuk berbulan madu mencari sorgaloka.

\section{Obyek dan Daya Tarik Wisatawan}

Obyek daya tarik wisata adalah penggerak utama pada sektor pariwisata. Untuk itu diperlukan kerjasama dari seluruh pemangku kepentingan dalam pengelolaannya. Pemerintah adalah fasilitator yang memiliki peran dan fungsi untuk membuat dan menentukan arah kebijakan pengembangan pariwisata. Daya tarik wisata adalah modal utama yang harus dimiliki untuk meningkatkan dan mengembangkan pariwisata. Obyek daya tarik wisata adalah mata rantai terpenting dalam suatu kegiatan wisata, hal ini disebabkan karena faktor utama yang membuat pengunjung atau wisatawan untuk mengunjungi suatu daerah tujuan wisata adalah potensi dan daya tarik wisata (Devy \& Soemanto, 2017).

Menurut Wondama et al., (2019) mengutip dari Cooper dkk. (1995) terdapat 4 (empat) unsur yang harus dimiliki oleh suatu objek wisata, yaitu: attraction, accessibility, amenity, dan ancilliary.

Attraction (Atraksi) adalah unsur signifikan untuk menarik wisatawan. Modal atraksi untuk menarik kedatangan wisatawan yaitu: atraksi Natural Resources (Alami), atraksi Budaya, dan Atraksi buatan manusia.

Accessibility (Aksesibilitas) adalah unsur yang disamakan dengan kemudahan untuk bergerak dari daerah yang satu ke daerah yang lain. Jika suatu daerah memiliki potensi pariwisata harus maka dilengkapi dengan aksesibilitas yang memadai sehingga daerah tersebut mudah untuk dikunjungi.

Amenity (Fasilitas atau Akomodasi) adalah unsur sarana dan prasarana yang diperlukan oleh wisatawan selama berada lokasi wisata, seperti: penginapan, rumah makan, tempat rekreasi, tempat berkemah, transportasi dan agen perjalanan. Prasarana yang diperlukan seperti: jalan raya, persediaan air atau toilet, tenaga listrik, tempat pembuangan sampah.

Ancilliary (pelayanan tambahan) adalah unsur yang harus disediakan oleh pengelola lokasi wisata.

\section{Minat Wisatawan}

Nuraeni (2014) mengutip dari Shadily (1987) minat yaitu kecenderungan bertingkah laku secara terarah terhadap kegiatan atau 
pengalaman tertentu. Minat dapat diartikan sebagai minat membeli yaitu dorongan konsumen untuk melakukan pembelian pertama kali atau pembelian ulang. Minat pembelian ulang merupakan perilaku didalam konteks terdapat konsep loyalitas. Konsumen atau pelanggan yang puas akan melakukan pembelian ulang dan memberitahukan kepada orang lain atas manfaat jasa yang didapatkannya. Informasi dan komponen kepuasan menjadi elemen penting pada siklus pembelian ulang, sehingga kegiatan mengukur minat beli kembali (future intention) pelanggan menjadi sangat penting.

\section{METODE PENELITIAN}

\section{Jenis Penelitian}

Jenis penelitian ini adalah deskriptif kuantitatif. Menurut Arikunto (2010) penelitian deskriptif adalah penelitian untuk menyelidiki hal-hal yang hasilnya dijelaskan dalam bentuk laporan penelitian, yaitu peneliti tidak mangubah, menambah, atau manipulasi objek penelitian. Peneliti hanya memotret apa yang terjadi pada objek yang diteliti..

\section{Waktu dan Lokasi Penelitian}

Penelitian dilakukan di Pantai Baru Yogyakarta beralamat di Ngentak, Poncosari, Kecamatan Srandakan, Bantul DIY. Penelitian dilaksanakan pada tahun 2019 yang dimulai dari bulan Oktober sampai dengan Maret 2020.

\section{Populasi Dan Sampel Penelitian}

Populasi dalam penelitian ini sebanyak 100 responden. Sedangkan Sampel dalam penelitian ini adalah wisatawan nusantara dengan umur 17 tahun keatas yang sedang dan pernah berkunjung ke obyek wisata Pantai Baru Yogyakarta. Penentuan sampel digunakan formula sebagai berikut Watson et al (1993):

$$
n=\frac{4 \cdot z \cdot \frac{1}{2} \cdot a \cdot p(1-p)}{(\omega)^{2}}
$$

Keterangan:

$\mathrm{n}=$ ukuran sampel

$\mathrm{p}=$ proporsi kesuksesan yang diharapkan sempel

$q=$ proporsi sisa $(1-p)$

$\mathrm{Z} 1 / 2 \mathrm{a}=$ koefisien- koefisien

$\omega=$ jumlah yang ditoleransi dari rata-rata populasi pada batas kiri (L) dan batas kanan $(\mathrm{R})$

Dengan asumsi $\mathrm{P}=\mathrm{q}=50 \%, \mathrm{a}=5 \%$ dan $\mathrm{Z}$ $1 / 2 \mathrm{a}=1,96, \mathrm{~L}=\mathrm{R}=10 \%$ sehingga $\omega=10 \%$ maka berdasarkan rumus diatas, maka dapat ditetapkan sampel sebanyak 100 orang sebagai berikut:

$$
\begin{aligned}
n & =\frac{4 \cdot(1,96)^{2} \cdot(0,05) \cdot(0,50)}{(2 \cdot 0,10)^{2}} \\
& =\frac{3,8416}{0,004} \\
& =96,4 \\
& =100 \text { orang }
\end{aligned}
$$

\section{Teknik Pengambilan Sampel}

Teknik pengambilan sampel adalah non probability sampling dengan metode purposive sampling yang merupakan bagian dari non probability sampling untuk mengambil sampel dari populasi berdasarkan kriteria tertentu yang ditetapkan oleh peneliti.

Purposive sampling dipilih berdasarkan pertimbangan jumlah populasi yang besar, sedangkan waktu untuk melakukan penelitian terbatas sehingga perlu diambil sampel yang dapat mewakili populasi. Kriteria yang digunakan adalah wisatawan yang berkunjung atau pernah berkunjung ke Pantai Baru selama tahun 2019 dengan usia 17 tahun keatas.

\section{Jenis Pengumpulan Data}

Pengumpulan data menggunakan data primer melalui wawancara atau hasil pengisian kuisioner (Umar, 2002). Data yang diperoleh berasal dari wisatawan yang sedang dan pernah berkunjung ke Pantai Baru Yogyakarta.

\section{Metode Pengumpulan Data}

Metode observasi yang dilakukan dengan penyebaran kuisioner untuk mengamati variabel obyek daya tarik wisata, aksesbilitas, dan minat wisatawan yang sedang berkunjung ke Pantai Baru.

Tabel 1. Kuisioner Responden

\section{Obyek Daya Tarik Wisata}

1 Pantai Baru sangat indah

2 Pantai Baru bersih dan nyaman

3 Pantai Baru menjadi tempat wisata edukasi untuk keluarga, seputar teknologi pembangkit listrik alternatif bertenaga matahari dan angin

4 Pantai Baru sering diadakan kegiatan pelepasan penyu yang dapat di saksikan langsung

5 Pantai Baru nyaman dan sejuk digunakan untuk memancing 
Aksesbilitas

1 Pantai Baru jaraknya dekat dengan rumah saya

2 Pantai Baru banyak petunjuk arah mudah untuk akses ke lokasi

3 Pantai Baru mudah untuk di jangkau karena transportasinya lancar

4 Pantai Baru mempunyai akses jalan yang baik

5 Pantai Baru mempunyai petunjuk arah ke setiap ke tempat di area pantai (tempat makan, mushola, kamar mandi)

\section{Minat Berkunjung Wisatawan}

1 Pantai Baru memberikan kesan senang kepada pengunjung

2 Pantai Baru memberikan pengunjung ingin kembali ke Pantai Baru

3 Pantai Baru harus di informasikan kepada teman/saudara karena menawarkan keunikan

4 Pantai Baru menawarkan keunikan maka saya ingin mengajak teman/saudara berkunjung ke Pantai Baru

5 Pantai Baru banyak tempat untuk berswafoto/shelfi

Sumber: (Penelitian, 2020)

\section{Variabel Penelitian}

Variabel penelitian terdiri dari variabel bebas (meliputi obyek daya tarik wisata $\left(X_{1}\right)$ dan aksesbilitas $\left(X_{2}\right)$ dan variabel terikat yaitu Minat Berkunjung Wisatawan $(Y)$.

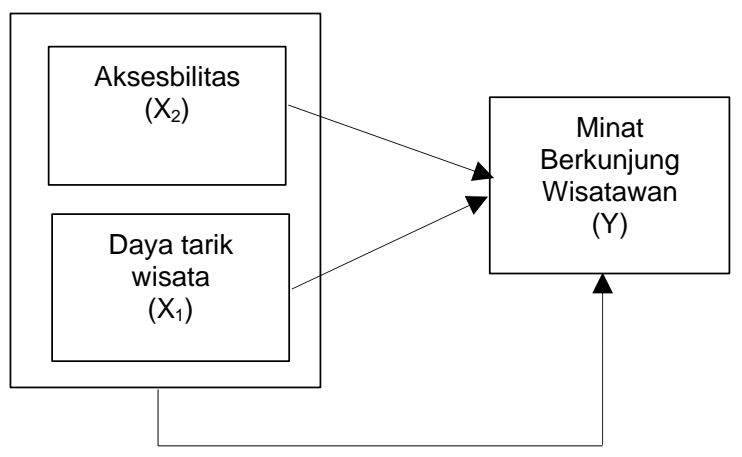

Sumber: (Penelitian, 2020)

Gambar 1. Kerangka Pemikiran

\section{HASIL DAN PEMBAHASAN}

\section{Uji Normalitas}

Uji normalitas untuk mengetahui apakah variabel bebas dan terikat mempunyai distribusi normal atau tidak (Santoso, 2000). Dasar pengambilan keputusan yaitu:
1. Jika data menyebar disekitar garis diagonal dan mengikuti arah garis diagonal, maka model regresi memenuhi asumsi normalitas;

2. Jika data menyebar jauh dari garis diagonal dan/atau tidak mengikuti arah garis diagonal, maka model regresi tidak memenuhi asumsi normalitas;

Normal P-P Plot of Regression Standardized Residual

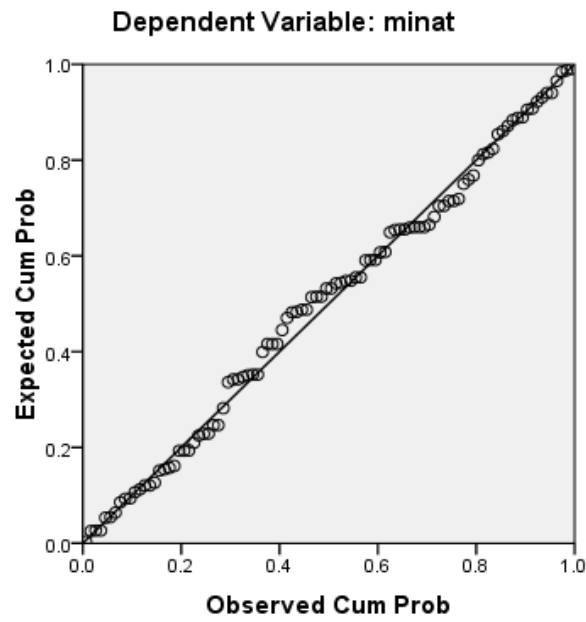

Sumber: (Penelitian, 2020)

Gambar 2. Grafik Normal P-P Plot

Gambar 2 diatas menunjukkan kedudukan titiktitik berada disekitar garis diagonal maka dapat disimpulkan data penelitian memenuhi asumsi normalitas.

\section{Uji Heteroskedastisitas}

Uji heteroskedastisitas dilakukan dengan tujuan untuk melihat apakah didalam model regresi terjadi ketidaksamaan varians dari residual, dari satu pengamatan ke pengamatan yang lain. Jika varians berbeda, dinamakan heteroskedastisitas (Santoso, 2000). Adanya heteroskedastisitas dapat dideteksi dengan:

1. Jika ada pola tertentu, seperti titik-titik yang ada membentuk suatu pola tertentu yang teratur (bergelombang, melebar, kemudian menyempit), maka telah terjadi heteroskedastisitas.

2. Jika ada pola yang jelas titik-titik menyebar diatas dan bawah angka 0 pada sumbu $Y$, maka tidak terjadi heteroskedastisitas. 
Scatterplot

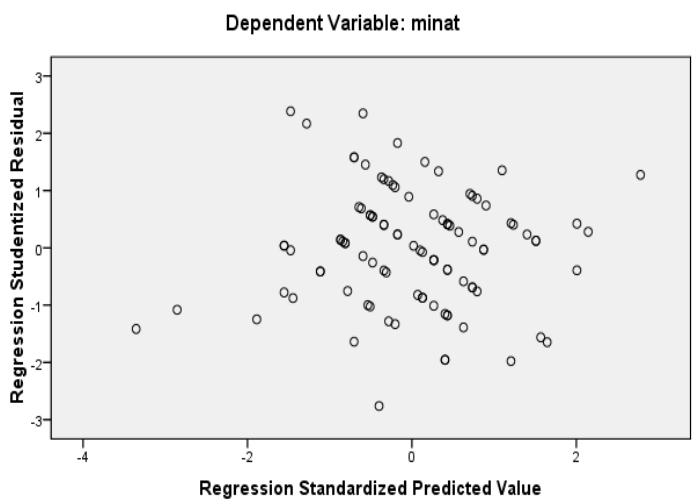

Sumber: (Penelitian, 2020)

Gambar 3 Grafik Scatterplot

Gambar 3 diatas menunjukkan kedudukan titiktitk menyebar diatas dan dibawah angka 0 pada sumbu Y maka dapat disimpulkan tidak terjadi heterokedasitas pada data penelitian.

\section{Uji Multikolinieritas}

Uji multikolinieritas untuk menguji apakah pada model regresi ditemukan adanya kolerasi antar variabel independen. Jika terjadi korelasi, maka dinamakan terdapat problem multikolinieritas (Santoso, 2000). Uji multikolineiritas yaitu VIF (Variance Inflation Factor) dan tolerance. Pedoman suatu regresi yang bebas multikolinieritas adalah mempunyai nilai VIF disekitar 1 dan mempunyai angka tolerance mendekati 1.

Tabel 2. Koefisien Multikolinieritas

\begin{tabular}{llcc}
\hline \multicolumn{4}{c}{ Coefficients $^{\text {a }}$} \\
\hline \multicolumn{4}{c}{ Collinearity Statistics } \\
Model & Tolerance & VIF \\
\hline 1 & odtw & .917 & 1.090 \\
& aksessibilitas & .917 & 1.090 \\
\hline \multicolumn{2}{l}{ a. Dependent Variable: minat } \\
\hline
\end{tabular}

Sumber: (Penelitian, 2020)

Tabel 2 diatas menunjukkan, koefisien multikolinieritas antara variabel obyek daya tarik wisata (odtw) dan aksesibilitas mendekati 1 yaitu 0,917 dengan nilai VIF disekitar 1 yaitu 1,090 , berarti pada model regresi tidak terjadi gejala multikolinieritas.

\section{Regresi Linier Berganda}

Menurut Mona et al., (2015) mengutip dari Supranto, J. (2004) Regresi linier berganda digunakan untuk mengetahui ada tidaknya pengaruh signifikan dua atau lebih variabel bebas) terhadap variabel terikat. Model regresi linier berganda untuk populasi dapat ditunjukkan sebagai berikut:

$$
Y=\beta_{0}+\beta_{1} X_{1}+\beta_{2} X_{2}+\ldots+\beta_{n} X_{n}+e
$$

Keterangan:

$Y=$ nilai penduga bagi variabel $Y$

$\beta_{0}=$ dugaan bagi parameter konstanta

$\beta_{\mathrm{n}}=$ dugaan bagi parameter konstanta $\beta 1, \beta 2, \ldots$, $\beta n$

Tabel 3. Koefisien Regresi

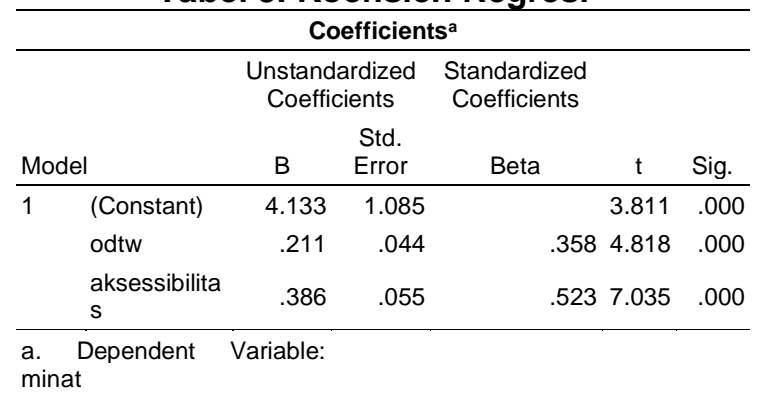

Sumber: (Penelitian, 2020)

Tabel 3 diatas menunjukkan persamaan regresi linier berganda yaitu:

$\mathrm{Y}_{\text {(minat) }}=4,133+0,211 \mathrm{X}_{1 \text { (odtw) }}+0,386 \mathrm{X}_{2 \text { (aksesebilitas) }}$

bahwa variable obyek daya tarik wisata (odtw) dan aksesibilitas berpengaruh positif terhadap minat berkunjung wisatawan secara signifikan lebih kecil dari 0,05.

\section{Uji t Parsial}

Menurut Suliyanto (2005) uji secara persial disebut juga uji t, dimaksudkan untuk mengetahui seberapa jauh signifikansi masingmasing variabel bebas terhadap variabel terikat.

Tabel 4. Uji t

\begin{tabular}{|c|c|c|c|c|c|}
\hline \multicolumn{6}{|c|}{ Coefficients $^{a}$} \\
\hline \multirow[b]{2}{*}{ Model } & \multicolumn{2}{|c|}{$\begin{array}{l}\text { Unstandardized } \\
\text { Coefficients }\end{array}$} & $\begin{array}{l}\text { Standardized } \\
\text { Coefficients }\end{array}$ & \multirow[b]{2}{*}{$\mathrm{t}$} & \multirow[b]{2}{*}{ Sig. } \\
\hline & $B$ & $\begin{array}{l}\text { Std. } \\
\text { Error }\end{array}$ & Beta & & \\
\hline 1 (Constant) & 4.133 & 1.085 & & 3.811 & .000 \\
\hline odtw & .211 & .044 & .358 & 4.818 & .000 \\
\hline aksessibilitas & .386 & .055 & .523 & 7.035 & .000 \\
\hline $\begin{array}{l}\text { a. Dependent } \\
\text { minat }\end{array}$ & Variable: & & & & \\
\hline
\end{tabular}

Sumber: (Penelitian, 2020)

Tabel 4 diatas menunjukkan variable variabel obyek daya tarik wisata (odtw) dan aksesibilitas secara terpisah berpengaruh positif terhadap minat berkunjung wisatawan dengan signifikan lebih kecil dari 0,05. 


\section{Uji F Simultan}

Menurut Suliyanto (2005) uji F atau uji koefisien regresi secara simultan atau serentak. Pengujian ini dilakukan untuk mengetahui seberapa jauh pengaruh masing- masing variabel bebas terhadap variabel terikat.

Tabel 5. Uji F

\begin{tabular}{|c|c|c|c|c|c|c|}
\hline \multicolumn{7}{|c|}{ ANOVA $^{b}$} \\
\hline \multicolumn{2}{|c|}{ Model } & \multirow{2}{*}{$\begin{array}{r}\begin{array}{c}\text { Sum of } \\
\text { Squares }\end{array} \\
160.030\end{array}$} & \multirow{2}{*}{$\frac{\mathrm{df}}{2}$} & \multirow{2}{*}{\begin{tabular}{r}
\multicolumn{1}{c}{$\begin{array}{c}\text { Mean } \\
\text { Square }\end{array}$} \\
80.015
\end{tabular}} & \multirow{2}{*}{$\frac{F}{50.242}$} & \multirow{2}{*}{$\frac{\text { Sig. }}{.000^{\mathrm{a}}}$} \\
\hline 1 & Regression & & & & & \\
\hline & Residual & 154.480 & 97 & 1.593 & & \\
\hline & Total & 314.510 & 99 & & & \\
\hline
\end{tabular}

a. Predictors: (Constant), aksessibilitas, odtw

b. Dependent Variable: minat

Sumber: (Penelitian, 2020)

Tabel 5 diatas diketahui bahwa besarnya $\mathrm{F}$ hitung 50,242 dan tingkat signifikansi 0,00 lebih kecil dari 0,05 , berarti variabel obyek daya tarik wisata (odtw) dan aksesibilitas secara simultan berpengaruh positif terhadap minat berkunjung wisatawan.

\section{Uji Koefisien Determinasi $\left(\mathbf{R}^{2}\right)$}

Uji determinasi untuk mengetahui berapa besar variabel bebas yang terdiri dari obyek daya tarik wisata dan aksebilitas dapat menjelaskan variabel terikat berupa minat berkunjung wisatawan.

Tabel 6. Koefisien Determinasi $\left(\mathbf{R}^{2}\right)$

\begin{tabular}{lcccc}
\hline \multicolumn{5}{c}{ Model Summary } \\
\hline Model & $R$ & R Square & $\begin{array}{c}\text { Adjusted R } \\
\text { Square }\end{array}$ & $\begin{array}{c}\text { Std. Error of the } \\
\text { Estimate }\end{array}$ \\
\hline 1 & $.713^{\text {a }}$ & .509 & .499 & 1.262 \\
\hline a. Predictors: (Constant), aksessibilitas, odtw
\end{tabular}

Sumber: (Penelitian, 2020)

Tabel 1.6 diatas menunjukkan, variabel obyek daya tarik wisata dan aksebilitas mempunyai hubungan yg kuat yaitu 0,713 ini lebih besar dari 0,05. R square sebesar 0,509 ini berarti kedua variable mempunyai pengaruh sebesar 0,509 terhadap minat berkunjung wisatawan berkunjung sedangkan sisanya 0,491 dipengaruhi oleh variable yang belum diamati.

\section{PENUTUP}

Dari hasil dan pembahasan dapat disimpulkan hasil uji $t$ dan uji $F$ menunjukkan variabel obyek daya tarik wisata dan aksebilitas berpengaruh positif terhadap minat berkunjung wisatawan dengan signifikan 0,00 dan besarnya pengaruh variabel obyek daya tarik wisata dan aksesbilitas terhadap minat berkunjung wisatawan 0,509 dan 0,491 dipengaruhi oleh variable yang belum diamati.

Mengingat banyaknya faktor yang mempengaruhi minat berkunjung wisatawan yang tidak dimasukkan pada penelitian ini, maka bagi penelitian selanjutnya dapat ditambahkan faktor-faktor sejenis atau faktor lainnya yang relevan untuk menghasilkan penelitian yang lebih baik lagi, dengan harapan minat berkunjung wisatawan ke Pantai Baru Yogyakarta dapat ditinjau secara lebih luas dengan berbagai sudut pandang tinjauan yang disajikan dalam jenis penelitian yang berbeda.

\section{DAFTAR PUSTAKA}

Arikunto. 2002. Metode Penelitian. Yogyakarta: Andi Offset

Devy, H. A., \& Soemanto, R. B. (2017). Pengembangan Obyek Dan Daya Tarik Wisata Alam Sebagai Daerah Tujuan Wisata Di Kabupaten Karanganyar (Studi Kasus Obyek Wisata Air Terjun Jumog di Kawasan Wisata Desa Berjo, Kecamatan Ngargoyoso, Kabupaten Karanganyar). Jurnal Sosiologi DILEMA, 32(1), 34-44.

Fajri, K., \& Riyanto E.S, N. (2016). Strategi Pengembangan Destinasi Pariwisata Kota Bandung Dalam Meningkatkan Tingkat Kunjungan Wisatawan Asal Malaysia. Tourism Scientific Journal, 1(2), 167-183. https://doi.org/10.32659/tsj.v1i2.9

Hakim, L. (2016). Industri Pariwisata dan Pembangunan Nasional. Among Makarti, 3(5), 70-78.

Mona, M., Kekenusa, J., \& Prang, J. (2015). Penggunaan Regresi Linear Berganda untuk Menganalisis Pendapatan Petani Kelapa. Studi Kasus: Petani Kelapa Di Desa Beo, Kecamatan Beo Kabupaten Talaud. D'CARTESIAN, 4(2), 196. https://doi.org/10.35799/dc.4.2.2015.9 211

Nuraeni, B. S. (2014). Analisis Faktor-Faktor Yang Mempengaruhi Minat Kunjung Ulang Wisatawan Museum Ranggawarsita Semarang. Jurnal Bisnis Strategi, 23(1), 1-20. Retrieved from

https://ejournal.undip.ac.id/index.php/j bs/article/viewFile/14113/10711

Santoso, S.2000. SPSS Statistik Paramatik. Jakarta. PT. Elek Media Komputindo 
Suliyanto, 2005. Analisa Data Dalam Aplikasi Pemasaran. Jakarta. Ghalia Indonesia

Umar, H. 2002. Riset pemasaran dan Perilaku Konsumen. Jakarta: Bussiness Research Center

Watson, C.J., P. Ballingsley. M., D.J. Croft., and D.V. Hundsbernger. 1993.

Wondama, K. T., Barat, P., Tingginehe, A. M., Waani, J. O., \& Wuisang, C. E. V.
(2019). Perencanaan Pariwisata Hijau Di Distrik Roon Kabupaten Teluk Wondama, Papua Barat. Spasial, 6(2), 511-520. 